\title{
Modified intralenticular lens aspiration for novice surgeons
}

\author{
Nidhi Kalra, Rahul Kumar Bafna 두, Mohamed Ibrahime Asif 다, Rajesh Sinha
}

Department of Ophthalmology, Dr Rajendra Prasad Centre for Ophthalmic Sciences, All India Institute of Medical Sciences, New Delhi, Delhi, India

\section{Correspondence to}

Dr Rahul Kumar Bafna; rahulbafnae@gmail.com

Accepted 4 June 2021

\section{DESCRIPTION}

Intralenticular lens aspiration (ILLA) has been described in patients with extensively subluxated crystalline lenses to achieve lens aspiration within the capsule, without any risk of lens matter falling posteriorly. ${ }^{12}$ The capsular bag is stabilised with the irrigation cannula's aid, which brings the area of interest into the surgeon's focus and hydrates the lens fibres, while the aspiration cannula performs the lens aspiration. However, this technique is challenging for a beginner surgeon as it involves bimanual hand-eye coordination under the microscope and assessment of the appropriate amount of traction to be applied with the irrigation cannula in this manoeuvre. Moreover, the visibility of the surgical field is dependent on the surgeon's hand movements and is not stable throughout the surgery.

We performed ILLA by modifying the technique and using a coaxial irrigation aspiration (IA) handpiece for the lens aspiration while stabilising the bag with a capsular hook. This step makes the surgeon's non-dominant hand free for stabilising the globe. It is simpler than a bimanual procedure, and lens stability is maintained throughout.

A 16-year-old woman with Marfan syndrome presented with corrected distance visual acuity 20/40 right eye and 20/25 left eye. On dilation, both eyes had superonasal subluxation of the crystalline lens. The right eye was planned for modified ILLA with scleral fixated intraocular lens (SFIOL) implantation.

The conjunctiva was dissected at 3 o'clock and 9 o'clock position, and the sclera was cauterised. On both sides, lamellar scleral flaps were created using a crescent blade, followed by sclerotomies under the flaps. ${ }^{3}$ A viscodispersive agent (Viscoat; Alcon Laboratries) was injected in the area of absent lens to tamponade the anterior vitreous. Then, $0.1 \mathrm{~mL}$ of trypan blue $0.06 \%$ (Visiblue) was injected under air with a sideways sweeping motion of the tip over the lens to prevent the dye from seeping into the vitreous and obstructing the red glow. A small capsulorrhexis of $1.5-2.0 \mathrm{~mm}$ in size was created on one side with a microrrhexis forceps (Microsurgical Technology), and a cohesive viscoelastic was injected into it to create space, followed by insertion of a capsular hook (Capsule Care, Madhu Instruments) from a 7 o'clock clear corneal incision. This helped to centre and stabilise the capsular bag. Another microrrhexis of 3.5-4 mm was created on the other side by the same technique. Balanced salt solution was injected through the larger opening to achieve a gentle hydromanouevre. A 3.2-mm clear corneal incision was created, and a coaxial IA handpiece

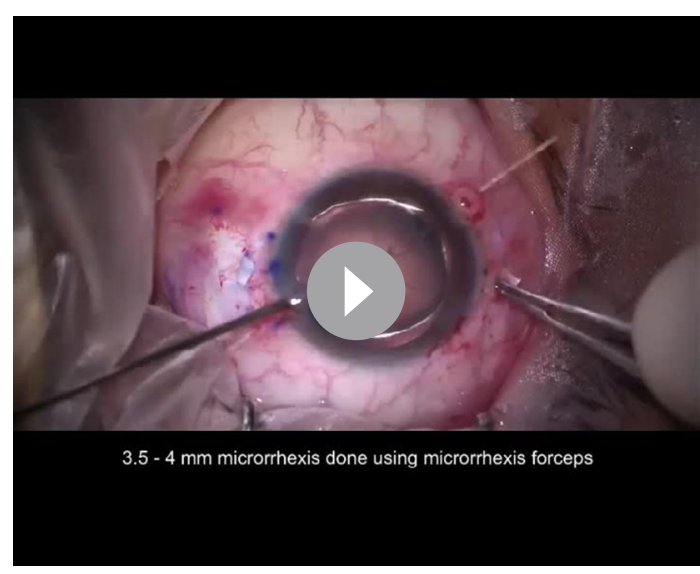

Video 1 Modified coaxial intralenticular lens aspiration.

was used to achieve complete lens aspiration. A vitrectomy cutter (Centurion system, $25 \mathrm{G}$, Alcon Laboratories) was used to remove the capsule, and a limited anterior vitrectomy was performed. Implantation of SFIOL was done with the handshake technique. The haptics were tucked in the scleral pockets, and scleral flaps and conjunctiva were closed with fibrin glue (Tisseel, Baxter Healthcare Corp). Stromal hydration was performed to close the paracentesis, and $3.2-\mathrm{mm}$ incision was sutured (video 1).

However, this technique requires careful attention to the amount of traction used during insertion of the capsular hook as excessive pull may lead

\section{Learning points}

- Intralenticular lens aspiration (ILLA) is challenging for a novice surgeon as it involves bimanual dexterity under the microscope in an extensively subluxated lens with inadequate zonular support and the visibility of surgical field is not constant.

- In the current modification of ILLA, using a capsular hook through a microrrhexis stabilises the capsular bag and allows the use of coaxial irrigation aspiration through the second microrrhexis.

- The surgeon's non-dominant hand is free to perform other manoeuvres and stabilise the globe, while the capsular bag visibility remains constant throughout surgery. 
to tears in the edge of microrrhexis. The sizing of the microrrhexis also needs to be adequate for insertion of the coaxial IA handpiece.

Contributors NK: concept and design, and drafting of work. RKB: concept and design, acquisition and interpretation of data, and revision of the work. MIA: interpretation of data and drafting of work. RS: revision of the work. All authors approved the work and take responsibility of the submission.

Funding The authors have not declared a specific grant for this research from any funding agency in the public, commercial or not-for-profit sectors.

Competing interests None declared.

Patient consent for publication Obtained.
Provenance and peer review Not commissioned; externally peer reviewed.

\section{ORCID iDs}

Rahul Kumar Bafna http://orcid.org/0000-0002-6795-0508

Mohamed Ibrahime Asif http://orcid.org/0000-0002-9949-3962

\section{REFERENCES}

1 Sinha R, Sharma N, Vajpayee RB. Intralenticular bimanual irrigation: aspiration for subluxated lens in Marfan's syndrome. J Cataract Refract Surg 2005;31:1283-6.

2 Sahay P, Maharana PK, Shaikh N, et al. Intra-lenticular lens aspiration in paediatric cases with anterior dislocation of lens. Eye 2019;33:1411-7.

3 Sinha R, Shekhar H, Gantyala SP, et al. Haptic placement of posterior chamber intraocular lens in fibrin glue-assisted intrascleral fixation. J Cataract Refract Surg 2013;39:1779-80.

Copyright 2021 BMJ Publishing Group. All rights reserved. For permission to reuse any of this content visit

https://www.bmj.com/company/products-services/rights-and-licensing/permissions/

BMJ Case Report Fellows may re-use this article for personal use and teaching without any further permission.

Become a Fellow of BMJ Case Reports today and you can:

- Submit as many cases as you like

- Enjoy fast sympathetic peer review and rapid publication of accepted articles

- Access all the published articles

Re-use any of the published material for personal use and teaching without further permission

\section{Customer Service}

If you have any further queries about your subscription, please contact our customer services team on +44 (0) 2071111105 or via email at support@bmj.com.

Visit casereports.bmj.com for more articles like this and to become a Fellow 